\title{
Casein induces the proliferation of bone marrow mononuclear cells, apoptosis of WEHI-3 leukaemic cells and increased survival in a leukaemia mouse model
}

\author{
E. LEDESMA-MARTÍNEZ ${ }^{1}$, C. PÉREZ-CORDERO ${ }^{1}$, Y. CÓRDOVA-GALAVIZ ${ }^{1}$, G. SÁNCHEZ-TELLEZ ${ }^{1}$, \\ S. HUERTA-YEPEZ ${ }^{2}$, I. AGUIÑIGA-SÁNCHEZ ${ }^{1}$, E. MIRANDA-PERALTA ${ }^{3}$, A. MONROY-GARCÍA ${ }^{4,5}$, \\ B. WEISS-STEIDER ${ }^{1}$ and E. SANTIAGO-OSORIO ${ }^{1}$
}

\footnotetext{
${ }^{1}$ Hematopoiesis and Leukaemia Laboratory, Research Unit on Cell Differentiation and Cancer, National Autonomous University of Mexico; ${ }^{2}$ Research Unit in Oncological Diseases, Childhood Hospital of Mexico "Federico Gómez";

${ }^{3}$ Cancer Research Unit, Oncology Hospital; ${ }^{4}$ Immunology and Cancer Laboratory, Medical Research Unit on Oncological Diseases, Mexican Social Security Institute (IMSS); ${ }^{5}$ Immunobiology Laboratory, Research Unit on Cell Differentiation and Cancer, National Autonomous University of Mexico, Mexico City, Mexico
}

Received January 16, 2012; Accepted April 10, 2012

DOI: $10.3892 / \mathrm{ol} .2012 .758$

\begin{abstract}
Acute myeloid leukaemia results from the neoplastic transformation of haematopoietic stem cells. Although advances have been made in its treatment, the mortality rate remains high. As a result, therapeutic alternatives continue to be explored. In this study, we present evidence that suggests that casein, the principal protein in milk, possesses significant antileukaemic properties. We investigated whether casein inhibited the in vitro proliferation and induced the apoptosis of the mouse myelomonocytic leukaemia cell line WEHI-3. By contrast, under identical conditions, casein markedly promotes the proliferation of mouse normal mononuclear bone marrow cells. Since the selective elimination of leukaemia cells is an ideal therapeutic strategy, we also evaluated the antileukaemic potential of casein in vivo. The results showed that casein increases the survival of mice bearing WEHI-3-induced tumours, suggesting that this molecule is also capable of inhibiting the proliferation of these cells in vivo. The evidence that casein inhibited cell proliferation and induced apoptosis in leukaemia cells in vitro, but increased survival in vivo in a
\end{abstract}

Correspondence to: Dr Edelmiro Santiago-Osorio, Hematopoiesis and Leukaemia Laboratory (L-8), Research Unit on Cell Differentiation and Cancer, UMIEZ, FES-Zaragoza Campus II, National Autonomous University of Mexico, Batalla 5 de mayo s/n, Col. E. Oriente, Esquina Fuerte de Loreto, Iztapalapa, CP 09230, Mexico City, Mexico

E-mail: edelmiro@unam.mx

Key words: sodium caseinate, BALB/c, acute myeloid leukaemia, cell line, leukaemia model leukaemia mouse model, indicates that casein may be useful in leukaemia therapy.

\section{Introduction}

Acute myeloid leukaemia is a neoplastic disease of blood stem cells that is characterised by the continuous clonal proliferation of myeloid precursors in the absence of differentiation or maturation into terminal cells (1). In spite of advances in leukaemia treatment, survival rates remain low, with 5-year survival rates of 60 and $10 \%$ in young and elderly patients, respectively (2). Thus, several new strategies are currently being developed (3).

Casein is the principal protein in milk and a significant component of the human diet that also regulates the proliferation and activation of blood cells. For example, $\beta$-casein, a component of bovine casein, has been found to activate free radical production in granulocytes and to induce lymphocyte proliferation (4). Casein also acts as an inflammatory agent that induces the migration of myeloid and lymphoid cells into the peritoneal cavity (5). In a previous study, we showed that casein inhibits the proliferation of the normal mouse myeloid cell line 32D by inducing its differentiation into the monocyte-macrophage lineage (6). Additionally, casein has been shown to inhibit the proliferation of several leukaemia cell lines (7).

An ideal therapeutic agent is one that selectively targets and kills cancer cells with minimal toxicity to normal tissues (8) and there are naturally occurring molecules that fulfill this requirement (9). As casein is able to induce the differentiation of the 32D cell line and inhibit leukaemia cells, the current study was performed to determine whether casein is capable of inducing the apoptosis of WEHI-3 and mononuclear bone marrow cells in vitro and inducing antileukaemic effects in vivo. The results of this study indicate that casein induces the apoptosis of leukaemia cells without exerting a cytotoxic 
effect on normal haematopoietic cells, thereby prolonging the survival of leukaemic mice.

\section{Materials and methods}

Experimental animals. BALB/c female mice between 8 and 12 weeks of age were used and maintained in pathogen-free conditions. Experiments were carried out in the animal facility of Facultad de Estudios Superiores Zaragoza, Universidad Nacional Autónoma de México, in accordance with institutional guidelines. Mice were provided with autoclaved water and fed a standard powdered rodent diet ad libitum. All experimental protocols were approved by the ethics committee of our institution in accordance with national and international regulations for the care and use of experimental animals.

Cell culture. The WEHI-3 murine myelomonocytic leukaemia cell line was obtained from ATCC (Rockville, MD, USA). The cells were cultured in Iscove's modified Dulbecco's medium (IMDM) (Gibco-BRL, Carlsbad, CA, USA) supplemented with $10 \%$ foetal bovine serum (FBS) (Gibco-BRL), $100 \mathrm{U} / \mathrm{ml}$ penicillin and $100 \mu \mathrm{g} / \mathrm{ml}$ streptomycin (Sigma-Aldrich, St. Louis, MO, USA). The cells were maintained in a humidified atmosphere containing $5 \% \mathrm{CO}_{2}$ at $37^{\circ} \mathrm{C}$ and the culture medium was changed every 2 days.

Total bone marrow cells of the mice were obtained from the femur and flushed with IMDM supplemented with $10 \%$ FBS. Mononuclear cells (MNCs) were obtained from the total cells via gradient separation with Ficoll-Paque (Amersham Biosciences AB, Uppsala, Sweden) at a density of $1.077 \mathrm{~g} / \mathrm{ml}$ and washed twice with phosphate-buffered saline (PBS). MNCs were cultured for $120 \mathrm{~h}$ in IMDM supplemented with $15 \%$ (v/v) FBS, 5\% (v/v) horse serum (Gibco-BRL) and $5 \mathrm{ng} / \mathrm{ml}$ recombinant mouse interleukin-3 (rmIL-3) (R\&D System, Minneapolis, MN, USA). The cells were maintained in a humidified atmosphere containing $5 \% \mathrm{CO}_{2}$ at $37^{\circ} \mathrm{C}$ and were maintained in culture for a maximum period of $120 \mathrm{~h}$.

Casein. Sodium caseinate, used as source of casein,(Spectrum, New Brunswick, NJ, USA) was dissolved in PBS at a concentration of $100 \mathrm{mg} / \mathrm{ml}$. Autoclaved dilutions were made with PBS to achieve concentrations of $0.5,1$ and $2 \mathrm{mg} / \mathrm{ml}$.

Proliferation assay. To evaluate cell proliferation, $3 \times 10^{3}$ and $750 \mathrm{WEHI}-3$ cells and $1 \times 10^{5} \mathrm{MNCs} / \mathrm{ml}$ were cultured for either 72 or $120 \mathrm{~h}$ with rmIL-3 and a range of casein concentrations $(0$, $0.5,1$ or $2 \mathrm{mg} / \mathrm{ml}$ ) in 24-well plates (Corning Costar, St. Louis, MO, USA). The cultures were then fixed with $1.1 \%$ glutaraldehyde and stained with crystal violet in $0.1 \%$ formic acid (Sigma-Aldrich). The dye was solubilised in $10 \%$ acetic acid and the optical density at $570 \mathrm{~nm}$ was determined using a plate reader (Tecan Spectra, Grödig, Austria).

Cell viability. Trypan blue exclusion assays were used to determine the number of viable cells in each culture. The cells were incubated in the presence or absence of $2 \mathrm{mg} / \mathrm{ml}$ of casein for $120 \mathrm{~h}$. Cell viability was determined by direct counting in a Neubauer chamber; cells excluding the stain were counted as viable. The results were shown as the mean percentage of cell viability \pm standard deviation (SD) of triplicate cultures.
Cell metabolic activity was quantified using the CellTiter $96{ }^{\circledR}$ aqueous non-radioactive cell proliferation (MTT) assay (Promega, Madison, WI, USA) according to the manufacturer's instructions. Briefly, following $120 \mathrm{~h}$ in the presence or absence of $2 \mathrm{mg} / \mathrm{ml}$ casein, $20 \mu \mathrm{l}$ of CellTiter 96 Aqueous One solution reagent was added to the plate, which was incubated for $4 \mathrm{~h}$. The absorbance at $490 \mathrm{~nm}$ was determined using a plate reader (Tecan Spectra).

Assessment of DNA fragmentation by agarose gel electrophoresis. WEHI-3 or MNCs cells $\left(1 \times 10^{6}\right)$ were lysed in DNA lysis buffer $\left(1 \% \mathrm{NPO}_{4}, 20 \mathrm{nM}\right.$ EDTA, $50 \mathrm{mM}$ Tris, $\left.\mathrm{pH} 7.9\right)$ at $47^{\circ} \mathrm{C}$ for $15 \mathrm{~min}$. The lysate was then centrifuged at $13,000 \mathrm{rpm}$ for $10 \mathrm{~min}$ at $47^{\circ} \mathrm{C}$. The supernatant containing the fragmented DNA was collected and incubated with $1 \%$ sodium dodecyl sulphate (SDS) and $2.5 \mu \mathrm{g} / \mathrm{ml}$ proteinase $\mathrm{K}$, followed by RNaseA-mediated RNA digestion at $37^{\circ} \mathrm{C}$ for $30 \mathrm{~min}$. Following extraction with phenol/chloroform/isoamyl alcohol (25:24:1), the DNA was precipitated in $50 \%$ isopropanol at $-20^{\circ} \mathrm{C}$ overnight. The precipitated DNA was centrifuged at 14,000 rpm for $30 \mathrm{~min}$, dried and dissolved in TE ( $\mathrm{pH}$ 8.0) buffer. Following electrophoresis in a $1 \%$ agarose gel containing ethidium bromide in TAE buffer, the DNA bands were observed with UV light.

Establishment of the mouse leukaemia model. WEHI-3 cells were washed twice with PBS, counted with trypan blue to confirm $>95 \%$ viability and adjusted to $2.5 \times 10^{4}$ cells $/ \mathrm{ml}$. $\mathrm{BALB} / \mathrm{c}$ mice were injected intraperitoneally (i.p.) with WEHI-3 cells and monitored for survival. The mice and their spleens, livers and tumour samples were obtained and weighed individually upon mortality or at the end of the 40 day period; respective indices were determined as the ratio of tumour or organ weight to body weight.

Electroporation procedure. The presence of leukaemia cells in the bone marrow was determined by the fluorescence microscopy of WEHI-3 cells electroporated with the pEGFP-C1 vector (Clontech, Mountain View, CA, USA). For the electroporation experiments, growing cell cultures at $60 \%$ confluence were collected and washed in room temperature IMDM-GlutaMAX-I (Gibco-BRL). Pre-chilled hypoosmolar electroporation medium $(0.8 \mathrm{ml})$ was added to the cell pellets $\left(5 \times 10^{6}\right.$ cells $\left./ \mathrm{ml}\right)$ either with or without $5 \mu \mathrm{g}$ of $\mathrm{pEGFP}-\mathrm{C} 1$ vector and the cells were electroporated at $250 \mathrm{~V}$ following a $5 \mathrm{~min}$ pre-incubation in the medium. Eight minutes after pulsing, the cells were gently transferred to $4 \mathrm{ml}$ of IMDM-GlutaMAX-I supplemented with $10 \% \mathrm{FBS}$ at $37^{\circ} \mathrm{C}$ and maintained at $5 \%$ $\mathrm{CO}_{2}$. The total time of cell exposure to the electroporation medium did not exceed $17 \mathrm{~min}$. The centrifuged cells were electroporated with a multiporator (Eppendorf AG, Hamburg, Germany) in disposable sterile electroporation cuvettes $(0.8 \mathrm{ml})$ with a $4-\mathrm{mm}$ gap between embedded aluminium electrodes (Eppendorf AG).

Antileukaemic activity in BALB/c mice. Four groups of $10 \mathrm{BALB} / \mathrm{c}$ mice were used. One group of mice was injected i.p. with $1 \mathrm{ml}$ of WEHI-3 cells. Another group was inoculated with WEHI-3 cells, with $10 \%$ casein in $1 \mathrm{ml}$ PBS added after $48 \mathrm{~h}$, and again every $48 \mathrm{~h}$, for 35 days. The third and fourth groups were inoculated with $1 \mathrm{ml}$ of PBS or casein, maintained 


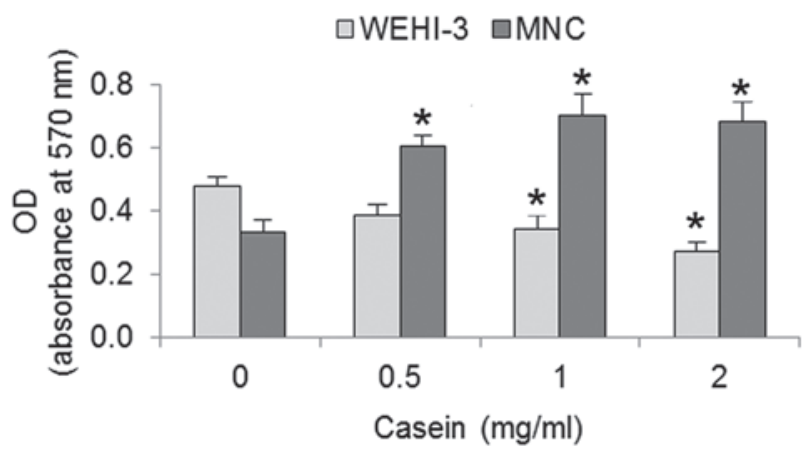

Figure 1. Proliferation of WEHI-3 leukaemia cells and normal bone marrow MNCs of BALB/c mice in the presence of $5 \mathrm{ng} / \mathrm{ml} \mathrm{rmIL-3} \mathrm{with} \mathrm{different}$ concentrations of casein. Each value is the mean \pm standard deviation of at least 3 independent assays. ${ }^{*} \mathrm{P}<0.05$. OD, optical density; rmIL-3, recombinant mouse interleukin-3; MNC, mononuclear cell.

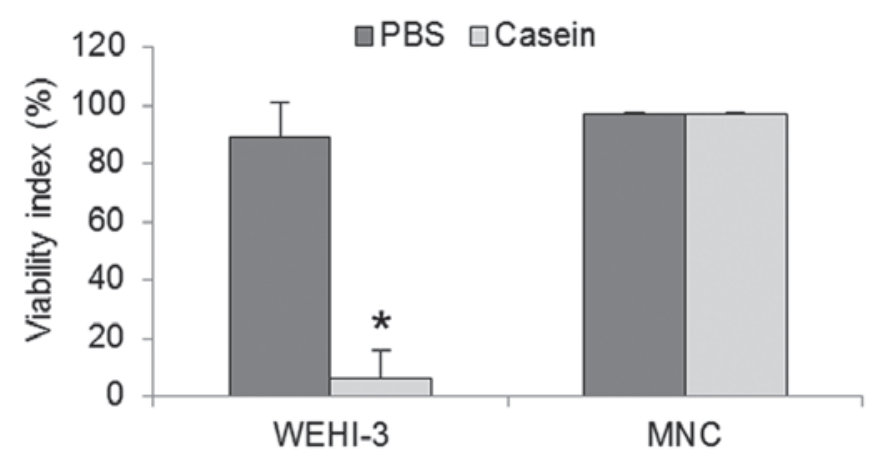

Figure 2. Viability of WEHI-3 cells and normal bone marrow MNCs of BALB/c mice in the presence of $5 \mathrm{ng} / \mathrm{ml} \mathrm{rmIL-3}$ with or without $2 \mathrm{mg} / \mathrm{ml}$ casein. Each value is the mean \pm standard deviation of at least 3 independent assays. ${ }^{*} \mathrm{P}<0.05$. rmIL-3, recombinant mouse interleukin-3; MNC, mononuclear cell; PBS, phosphate-buffered saline.

as controls and observed for survival during the 40 day time course. At 3 weeks from the start of treatment, the mice were sacrificed and tissues were weighed individually.

Statistical analysis. Individual experiments were carried out in triplicate. The experiments were repeated three times and values were shown graphically as the mean $\pm \mathrm{SD}$. One-way ANOVA was used for statistical analysis. $\mathrm{P}<0.05$ was considered to indicate a statistically significant result. Statistical software (SPSS, Inc., Chicago, IL, USA) was used to perform the analyses.

\section{Results}

Casein inhibits the proliferation of WEHI-3 cells and induces the proliferation of bone marrow MNCs. To homologise the culture conditions of the WEHI-3 cells and MNCs, we cultured 750 and $1 \times 10^{5}$ cells $/ \mathrm{ml}$, respectively, with $5 \mathrm{ng} / \mathrm{ml}$ of $\mathrm{rmIL}-3$ for $120 \mathrm{~h}$ in the presence or absence of $0.5,1$ or $2 \mathrm{mg} / \mathrm{ml}$ casein. Using crystal violet, we evaluated the number of cells present. The number of WEHI-3 cells were decreased and the number of MNCs were increased as a function of casein concentration (Fig. 1). At $2 \mathrm{mg} / \mathrm{ml}$ casein, the inhibition of the WEHI-3 cells was $>40 \%$, while the induced proliferation of the MNCs was $>50 \%$ compared with the control.

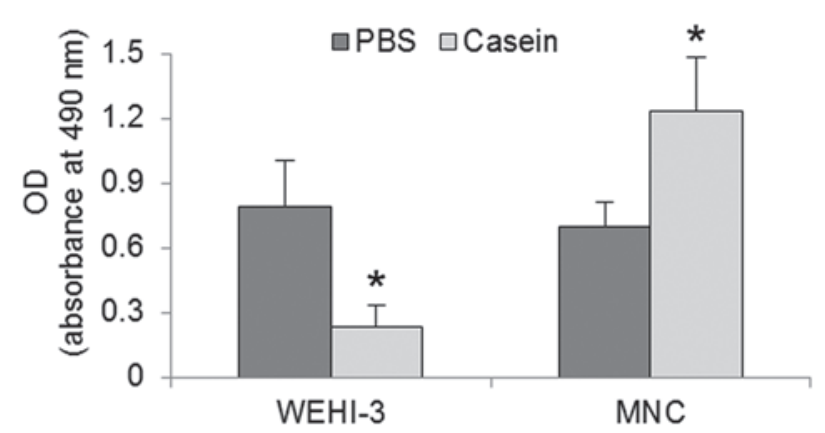

Figure 3. Viability assessed as metabolic activity of WEHI-3 cells and normal bone marrow MNCs of BALB/c mice in the presence of $5 \mathrm{ng} / \mathrm{ml}$ rmIL-3 plus $2 \mathrm{mg} / \mathrm{ml}$ of casein. Each value is the mean \pm standard deviation of a representative test with 4 replicates per condition. ${ }^{*} \mathrm{P}<0.05$. OD, optical density; PBS, phosphate-buffered saline; rmIL-3, recombinant mouse interleukin-3; MNC, mononuclear cell.

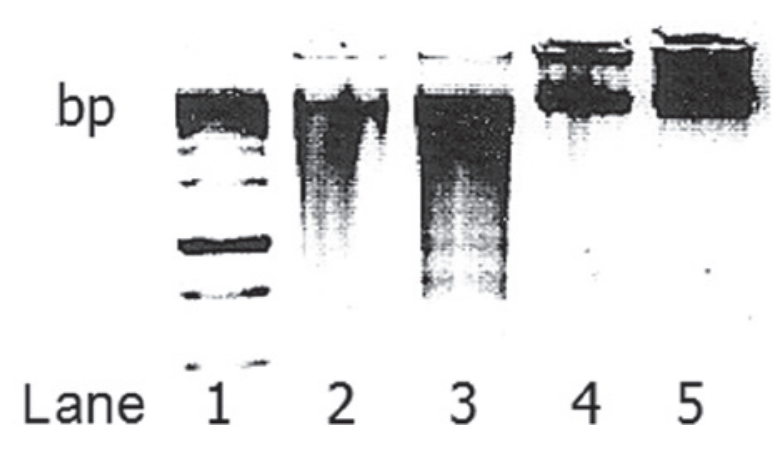

Figure 4. DNA fragmentation, detected via agarose gel electrophoresis, in WEHI-3 or MNC cultures in the presence of $5 \mathrm{ng} / \mathrm{ml} \mathrm{rmIL-3.} \mathrm{Lane} \mathrm{1,} \mathrm{marker}$ (bp); lane 2, WEHI-3 plus PBS; lane 3, WEHI-3 plus $2 \mathrm{mg} / \mathrm{ml}$ casein; lane 4, MNC plus PBS; line 5, MNC plus $2 \mathrm{mg} / \mathrm{ml}$ casein. Results are representative of 2 separate experiments. bp, base pairs; MNC, mononuclear cell; PBS, phosphate-buffered saline.

Casein reduced metabolic activity and induced cell death in WEHI-3 cells, but did not impair the viability of MNCs. Following the observation that casein inhibited the proliferation of WEHI-3 cells and induced the proliferation of MNCs, we evaluated the viability of those cells when cultured in the presence of $2 \mathrm{mg} / \mathrm{ml}$ casein. Results of the trypan blue exclusion assay revealed that the viability was $<90 \%$ in the WEHI-3 cells but was not reduced in the MNCs (Fig. 2). To evaluate the status of the two cell types, we performed the MTT assay to determine their metabolic activities. In response to the casein treatment, we observed that WEHI-3 cells exhibited a $75 \%$ reduction in activity, while MNCs showed an increase of their baseline rate by $50 \%$ relative to the control (Fig. 3). The near-complete loss of viability of WEHI-3 cells and the existence of significant metabolic activity, indicated that cell death may have resulted from an active cell mechanism.

Casein induced DNA fragmentation in WEHI-3 cells but not in MNCs. To evaluate whether the casein-induced death in the WEHI-3 cells resulted from an apoptotic mechanism, we examined the fragmentation of DNA in those cells following a 120 -h incubation with $2 \mathrm{mg} / \mathrm{ml}$ casein. Our results showed that, for the WEHI-3 cells, casein induced the typical apop- 
Table I. Treatment of control or leukaemic mice with and without casein treatment.

\begin{tabular}{lccccc}
\hline & \multicolumn{2}{c}{ PBS-1 } & & \multicolumn{2}{c}{ WEHI-3 } \\
\cline { 2 - 3 } \cline { 5 - 6 } Index & PBS-2 & Casein & & PBS-2 & Casein \\
\hline Hepatic & $0.066 \pm 0.019$ & $0.046 \pm 0.005$ & & $0.127 \pm 0.048^{\mathrm{a}}$ & $0.081 \pm 0.032^{\mathrm{a}}$ \\
Splenic & $0.004 \pm 0.0003$ & $0.002 \pm 0.004$ & & $0.008 \pm 0.002^{\mathrm{a}}$ & $0.006 \pm 0.001^{\mathrm{a}}$ \\
Tumoural & ND & ND & & $0.107 \pm 0.093^{\mathrm{a}}$ & $0.035 \pm 0.002^{\mathrm{a}}$ \\
\hline
\end{tabular}

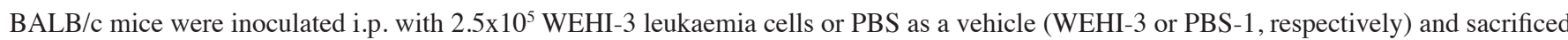
for examination of necropsy 3 weeks after the start of treatment with $10 \%$ casein or vehicle alone (Casein or PBS-2, respectively). Each animal was weighed individually prior to autopsy. The mice spleens, livers and tumour samples were then obtained and weighed individually. Each value is the mean \pm standard deviation of 3 autopsies. ${ }^{\mathrm{P}}<0.05$. ND, not determined; i.p., intraperitoneally; PBS, phosphate-buffered saline.
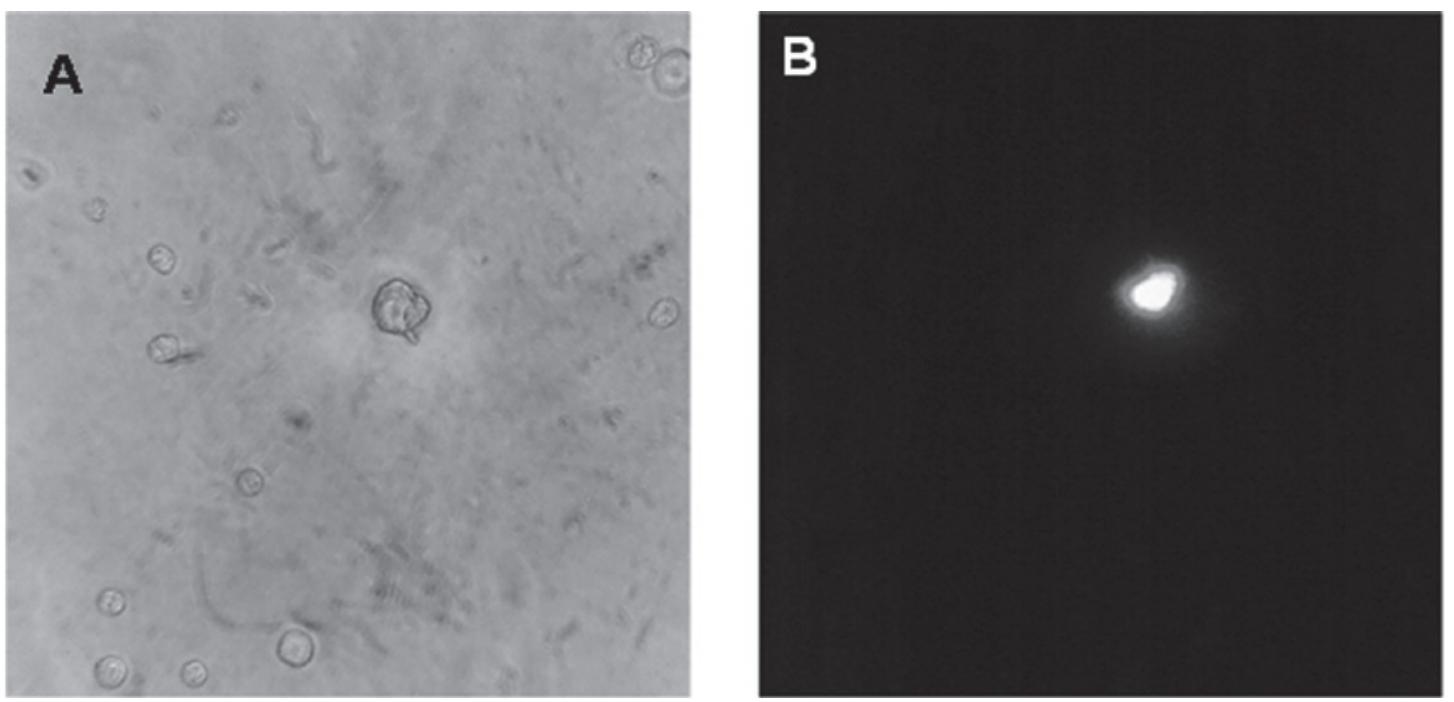

Figure 5. WEHI-3/GFP ${ }^{+}$cell infiltration in the bone marrow of BALB/c mice, $24 \mathrm{~h}$ after intraperitoneal inoculation. (A) Phase contrast. (B) UV. Representative images at $\mathrm{x} 40$ magnification.

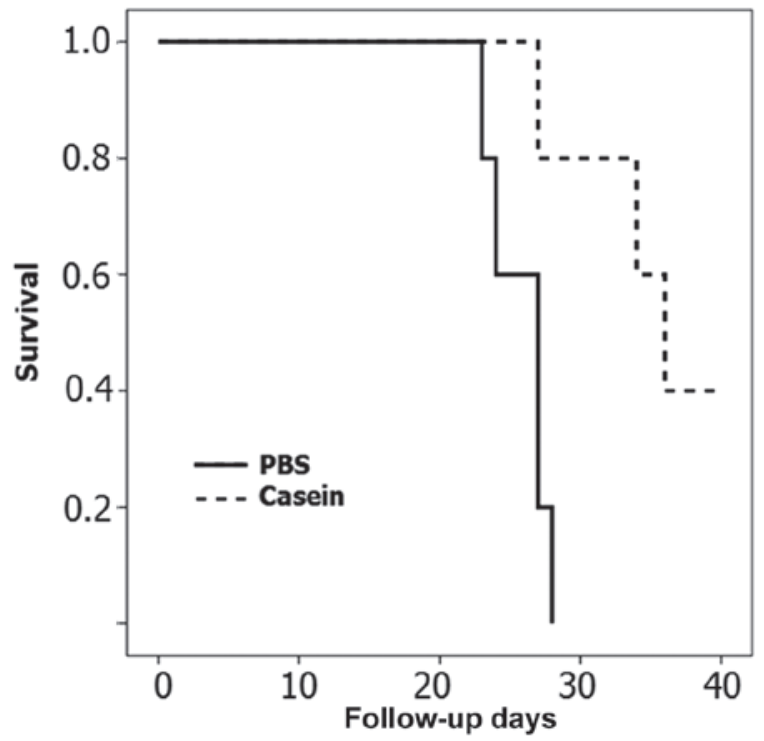

Figure 6. Survival of BALB/c leukaemic mice treated with $1 \mathrm{ml}$ of vehicle (WEHI-3/PBS) or 10\% casein in PBS w/v (WEHI-3/Casein) every $48 \mathrm{~h}$. Healthy mice treated only with casein (Casein) were included as a control. Kaplan-Meier curve. $n=10$ per group. PBS, phosphate-buffered saline. totic stair pattern in the agarose gels; by contrast, this pattern was not observed for the MNCs (Fig. 4). Therefore, our results suggest that casein not only inhibits the proliferation, but also induces the apoptosis, of WEHI-3 cells.

Establishment of a BALB/c-WEHI-3 leukaemia model. Following the observation that casein was toxic to leukaemia cells but promoted normal myeloid proliferation, we developed a mouse leukaemia model to evaluate the antileukaemic potential of casein. Our results showed that animals challenged with WEHI-3 cells developed marked splenomegaly and hepatomegaly and solid tumours (Table I), resulting in the death of all experimental subjects within 30 days.

WEHI-3 cells infiltrated the bone marrow of mice inoculated i.p. at $24 \mathrm{~h}$. We determined whether WEHI-3 cells were able to migrate out of the peritoneal cavity during the $48 \mathrm{~h}$ prior to treatment with casein in our mouse leukaemia model. Therefore, we evaluated the simultaneous injection of cells transiently transfected with the pEGFP-1 vector to determine whether WEHI-3 cells were present in the bone marrow $24 \mathrm{~h}$ after inoculation. Our results showed that WEHI-3 cells 
migrated to the bone marrow within one day of i.p. inoculation (Fig. 5).

Casein reduced hepatomegaly and tumour burden and increased the survival of mice inoculated with WEHI-3 cells. Leukaemia was induced by WEHI-3 cells as described above and our results showed that treatment with casein markedly reduced hepatomegaly and the presence of solid tumours (Table I). Conversely, we observed that animals not treated with casein died by day 28 , while those treated with casein survived for longer, having a $40 \%$ survival rate after 40 days (Fig. 6). Together with the increased survival of mice treated with casein, the decreased liver and tumour indices indicate that casein inhibited the proliferation and induced the apoptosis of WEHI-3 cells.

\section{Discussion}

Leukaemia cells undergo physiological alterations that contribute to their self-sufficiency for survival, unlimited growth capacity, apoptosis avoidance mechanisms and arrest of cell differentiation, all of which collectively characterise their malignant nature $(10,11)$. Drugs including anthracyclines and cytarabine are usually used to treat leukaemia, but survival rates are low, with a $60 \% 5$-year survival rate in young patients and a $10 \%$ survival rate for elderly patients (2). Given the side effects and poor tolerance by elderly patients of these treatments (12), there is a pressing need for new therapeutic alternatives (13).

We previously reported that casein inhibited the proliferation of the myelomonocytic cell line WEHI-3 (7). In the present study, we have provided evidence that casein also induces apoptosis in WEHI-3 cells. Casein is known to induce the differentiation of the normal mouse myeloid cell line 32D into a monocyte-macrophage lineage (6), thus we expected a similar response in MNCs. However, casein induced a marked proliferation stimulus. These data are significant since the usefulness of a potential anticancer compound depends not only on its cytotoxicity towards malignant cells, but also on a relative lack of toxicity in normal tissues (8). There is evidence to show that normal tissues may be less sensitive to the biological effects of new molecules with potential antileukaemic properties. It has previously been shown that betulinic acid reduces the metabolic activity of WEHI-3 cells, but requires concentrations 10 times higher to achieve the same effect in normal human lymphocytes (14). Curcumin induces apoptosis in more than $80 \%$ of $\mathrm{CD}_{34}{ }^{+}$cells from patients with AML, but the same concentration is cytotoxic in only $20 \%$ of normal cells (9).

Similar to a number of agents studied thus far (15), casein inhibits proliferation and induces the death of leukaemia cells. However, in addition to exerting no cytotoxicity on nonleukaemia MNCs, casein induces their proliferation, which is a rare property among the majority of drugs tested for use in the treatment of acute myeloid leukaemia. Therefore, we evaluated the possibility of using casein as an antileukaemic agent in vivo.

The i.p. inoculation of leukaemia WEHI-3 cells in BALB/c mice has been described as an ideal model for the study of novel therapeutics (e.g., ATRA, aclacinomycin A, IL-6, G-CSF and vitamin D3) (16). To determine whether the leukaemia was restricted to the peritoneal cavity, we evaluated whether i.p.-inoculated WEHI-3 cells were able to migrate to the bone marrow. We observed that WEHI-3 cells were present in the marrow of inoculated mice as early as $24 \mathrm{~h}$ post-inoculation, demonstrating the ability of these cells to colonise secondary sites. This observation demonstrates their aggressive nature, which resulted in the mortality of all animals tested within 30 days.

When casein was injected i.p., it reduced the tumour burden and suppressed hepatomegaly, which collectively increased the survival of the leukaemic mice by a significant extent; this was considered to be evidence of the inhibition of the growth of WEHI-3 cells in vivo (17). Therefore, casein exhibits antileukaemic properties in vitro and in vivo, which is in contrast to the antibody gemtuzumab ozogamicin, which efficiently eliminates leukaemia $\mathrm{CD} 33^{+}$cells in vitro but does not improve the survival of leukaemic individuals (18).

Whether the antitumour properties exhibited in our leukaemia mouse model resulted from the large induction of inflammatory cell migration to the peritoneal cavity or from the secretion of inflammatory differentiation or growth factors known to be induced in vivo is unclear (19). Alternatively, it is possible that these effects resulted from the bioactive components of casein, products of the phagocyte-mediated digestion of casein (20) or a combination of these factors. Due to its size, casein does not enter the bloodstream, but several of its components do. Furthermore, biopeptide derivatives of casein have been detected in blood plasma for several hours following the ingestion of milk (21).

In conclusion, casein is not cytotoxic to normal cells but has an inductive effect of haematopoiesis in vitro. Conversely, under the same conditions, casein induces apoptosis in leukaemia cells and prolongs the survival of leukaemic mice, which is clear evidence of antileukaemic activity.

\section{Acknowledgements}

We would like to thank Mr. Ernesto J. Rivera Rosales for the excellent technical assistance. We are indebted to CONACYT for a Ph.D. scholarship to LME (48959); CGY (169059); a Master scholarship to ASI (247169); and an undergraduate scholarship to PCC (15750). This study was supported in part by Fondo SEP-CONACYT (grant 104025) and PAPIT (grant IN225610). Professor Ledesma-Martínez acknowledges the Graduate Program in Biological Sciences of the National Autonomous University of México (UNAM) for the training received during the studies.

\section{References}

1. Gregory TK, Wald D, Chen Y, Vermaat JM, Xiong Y and Tse W: Molecular prognostic markers for adult acute myeloid leukemia with normal cytogenetics. J Hematol Oncol 2: 23-33, 2009.

2. Robak T and Wierzbowska A: Current and emerging therapies for acute myeloid leukemia. Clin Ther 31: 2349-2370, 2009.

3. Kuendgen A and Germing U: Emerging treatment strategies for acute myeloid leukemia (AML) in the elderly. Cancer Treat Rev 35: 97-120, 2009.

4. Wong CW, Seow HF, Liu AH, Husband AJ, Smithers GW and Watson DL: Modulation of immune responses by bovine betacasein. Immunol Cell Biol 74: 323-329, 1996.

5. Metcalf D, Robb L, Dunn AR, Mifsud S and Di Rago L: Role of granulocyte-macrophage colony-stimulating factor and granulocyte colony-stimulating factor in the development of an acute neutrophil inflammatory response in mice. Blood 88: 3755-3764, 1996. 
6. Ramos G, Santiago E, Martínez I, Zambrano I, Manrique B and Weiss B: Sodium caseinate induces differentiation of 32D pluripotential hematopoietic cells. Rev Invest Clin 52: 638-644, 2000.

7. Ramos-Mandujano G, Weiss-Steider B, Melo B, Cordova Y, Ledesma-Martinez E, Bustos S, Silvestre O, Aguiniga I, Sosa N, Martinez I, et al: Alpha-, beta- and kappa caseins inhibit the proliferation of the myeloid cell lines 32D cl3 and WEHI-3 and exhibit different differentiation properties. Immunobiology 213 : 133-141, 2008

8. Lickliter JD, Wood NJ, Johnson L, McHugh G, Tan J, Wood F, Cox J and Wickham NW: HA14-1 selectively induces apoptosis in Bcl-2-overexpressing leukemia/lymphoma cells, and enhances cytarabine-induced cell death. Leukemia 17: 2074-2080, 2003.

9. Rao J, Xu DR, Zheng FM, Long ZJ, Huang SS, Wu X, Zhou WH, Huang RW and Liu Q: Curcumin reduces expression of Bcl-2, leading to apoptosis in daunorubicin-insensitive $\mathrm{CD} 34^{+}$acute myeloid leukemia cell lines and primary sorted CD $34^{+}$acute myeloid leukemia cells. J Trans Med 9: 71-86, 2011.

10. Hanahan D and Weinberg RA: The hallmarks of cancer. Cell 7: 57-70, 2000.

11. Montesinos JJ and Mayani $\mathrm{H}$ : New concepts in the biology of acute myeloid leukemia. Gac Med Mex 138: 67-76, 2002 (In Spanish)

12. Tallman MS, Gilliland DG and Rowe JM: Drug therapy for acute myeloid leukemia. Blood 106: 1154-1163, 2005.

13. Roboz GJ: Novel approaches to the treatment of acute myeloid leukemia. Hematology Am Soc Hematol Educ Program 2011: 43-50, 2011.
14. Faujan NB, Alitheen SK, Yeap AM, Ali AH, Muhajir FB and Ahmad H: Cytotoxic effect of betulinic acid and betulinic acid acetate isolated from Melaleuca cajuput on human myeloid leukemia (HL-60) cell line. Afr J Biotechnol 9: 6387-6396, 2010.

15. Shipley J and Butera J: Acute myelogenous leukemia. Exp Hematol 37: 649-658, 2009.

16. He Q and $\mathrm{Na} X$ : The effects and mechanisms of a novel 2 aminosteroid on murine WEHI3B leukemia cells in vitro and in vivo. Leuk Res 25: 455-461, 2001.

17. Yoon JS, Kim JY, Park HK, Kim ES, Ahn KS, Yoon SS, Cho CG, Kim BK and Lee YY: Antileukemic effect of a synthetic vitamin D3 analog, HY-11, with low potential to cause hypercalcemia. Int J Oncol 32: 387-396, 2008.

18. Majeti R: Monoclonal antibody therapy directed against human acute myeloid leukemia stem cells. Oncogene 30: 1009-1019, 2010

19. Noursadeghi M, Bickerstaff MCM, Herbert J, Moyes D, Cohen J and Pepys MB: Production of granulocyte colony-stimulating factor in the nonspecific acute phase response enhances host resistance to bacterial infection. J Immunol 169: 913-919, 2002.

20. Russell MW, Brooker BE, and Reiter B: Electron microscopic observations of the interaction of casein micelles and milk fat globules with bovine polymorphonuclear leucocytes during the phagocytosis of staphylococci in milk. J Comp Pathol 87: 43-52, 1977.

21. Chabance B, Marteau P, Rambaud J, Migliore D, Boynard M, Perrotin P, Jollès $\mathrm{P}$ and Fiat AM: Casein peptide release and passage to the blood in humans during digestion of milk or yogurt. Biochimie 80: 155-165, 1998. 